\title{
The Effect of Age and Parity on Hypertension during Pregnancy
}

\author{
Suryo Pratikwo*, Ida Baroroh, Agustiana Resghyanti \\ Politeknik Kesehatan, Kemenkes Semarang, Jl. Tirto Agung Pedalangan, Banyumanik, Indonesia \\ *Corresponding Author: Suryo Pratikwo Politeknik Kesehatan, Kemenkes Semarang, Jl. Tirto Agung \\ Pedalangan, Banyumanik, Indonesia, Email: d3keperawatan-pkl@poltekkes-smg.ac.id
}

\section{Abstract}

Background: Age and parity are one of the predisposing factors of hypertension in pregnancy. The decline in maternal mortality in Indonesia is still too slow to achieve the millennium development goals of reducing the mortality rate.

The Objective: This study aims to determine the relationship between age and parity with the incidence of hypertension in pregnancy at the General Hospital Kraton Pekalongan, Indonesia.

Method: The independent variable in this study is age and parity, while the dependent variable is hypertension in pregnancy. This study used a descriptive correlative design with a population of 367 people and used the total sample.

Result: The result of correlation test using Spearman Rank shows there is a correlation between age with the incidence of hypertension in pregnancy with p-value 0.029 and value of r-0.114. In the other hand, the relationship between parity with the prevalence of hypertension in pregnancy obtained p-value 0.006 and the value of $r-0.143$.

Conclusion: There is a relationship between age and parity with the incidence of hypertension in pregnancy. This way, the health service is expected to increase the extension activities, especially about hypertension in pregnancy and parity to pregnant women so that the incidence of hypertension in pregnancy and maternal mortality rate may decrease.

Keywords: Age, Parity, Hypertension in Pregnancy

\section{INTRODUCTION}

In general, the measure used to assess the service quality of maternity care in a country or region is maternal mortality. Maternal death is the death of a woman during pregnancy or within 42 days after the end of gestation by any cause.

Mortality and morbidity in pregnant and maternal women is a major problem in developing countries, around $25-50 \%$ of women of childbearing age are due to pregnancy. Maternal mortality is usually a major factor in the death of young girls during peak productivity (Prawirohardjo, 2009).

According to Indonesia Demographic and Health Survey, maternal mortality rate in Indonesia is still high at 228 per 100,000 live births. The decline in maternal mortality rate in Indonesia is still too slow to reach the millennium development goals target of reducing the maternal mortality rate by threequarters during pregnancy and childbirth.

In Indonesia, mortality and morbidity of hypertension in pregnancy are also still high enough that is about 5-15\%. Pregnancy complication is one of the factors leading to maternal mortality and morbidity (Prawiro hardjo, 2008).

According to data of outpatient medical record at Kraton Pekalongan General Hospital, the maternal mortality rate from 2009 to 2011 has increased with the highest case due to preeclampsia. The cause of maternal mortality in Pekalongan Kraton General Hospital include: bleeding 4 cases, Eclampsia 16 cases, Sepsis 4 cases and 6 cases due to other causes.

Hypertension in pregnancy is one of the causes of maternal death. Factors of age and parity are also factors that can support the occurrence of hypertension in pregnancy. Therefore, researchers are interested in examining the 
relationship between age and parity with hypertension occurrence in pregnancy at the general hospital of Kraton, Pekalongan, Indonesia.

\section{Materials And Methods}

The independent variables in this study were age and parity. Age is the length of life counted from birth to the present. Age is a period of new life patterns; the increasing age will reach the age of reproduction. Age 20-30 years is the safest time to pregnancy or childbirth, in women aged over 40 years, the incidence of hypertension in pregnancy tripled compared with the ladies aged 20-30 years. Parity is the number of live births a woman has.

Parity classification is as follows:

1. Nullipara: A woman who has never delivered a baby viable.

2. Primipara: The woman who gave birth to a baby for the first time.

3. Multipara: A woman who has given birth viable baby several times (up to 5 times).

4. Grande multipara: Women who have given birth to babies six or more times live or die.

The dependent variable in this study was hypertension in pregnancy. Pregnancy is defined as fertilization or unification of spermatozoa and ovum then followed by nidation or implantation. Healthy pregnancy usually lasts nine calendar months, or 40 weeks or 280 days. The length of pregnancy is calculated from the first day of the last menstrual period. The definite signs of pregnancy are apparent findings of fetal existence, and this can not be explained by other health conditions. Hypertension in pregnancy is an increase in blood pressure before 20 weeks of gestation accompanied by headaches, blurred vision, convulsions, and decreased consciousness. Pregnancy-induced hypertension is a disorder with an unknown etiology that is specific to pregnant women characterized by high blood pressure, comprehensive edema and urine protein occurring after 20 weeks of gestation.

This research is a type of the investigation with a quantitative approach which emphasizes the analysis of numerical data (number) processed using a statistical method. With this method, it will be obtained significance of group differences or importance of relationships among variables studied. This research uses descriptive correlative design to find out the relationship between two or more variables.
The population in this study is all pregnant women who do the examination in gynecology as much as 367 people. This study took the entire population to be sampled as many as 367 people.

After data collection, the analysis applies computer software of SPSS 16. The analysis in this research using Spearman rank statistical test. This study uses an alternative hypothesis (Ha) which states the relationship between two or more variables, namely:

1. There is a relationship between age with the incidence of hypertension in pregnancy

2. There is an association between parity with the prevalence of hypertension in pregnancy.

\section{RESULT AND DISCUSSION}

\section{Result}

Characteristics of respondents are presented in the following tables.

Table1. Frequency distribution of pregnant women's of age

\begin{tabular}{|c|c|c|}
\hline Ages & Frequency $(\mathrm{n})$ & Percentage $(\%)$ \\
\hline$<20$ years & 11 & 3.0 \\
\hline $20-35$ years & 262 & 71.4 \\
\hline$<35$ years & 94 & 25.6 \\
\hline Total & 367 & 100.0 \\
\hline
\end{tabular}

Table 1 shows that the highest number of pregnant women in the 20-35 years age group which is $262(71.4 \%)$.

Table2. Frequency distribution of pregnant women' parity

\begin{tabular}{|c|c|c|}
\hline Parity & Frequency $(\mathrm{n})$ & Percentage (\%) \\
\hline Nullipara & 140 & 38.1 \\
\hline Primipara & 110 & 30.0 \\
\hline Multipara & 106 & 28.9 \\
\hline $\begin{array}{c}\text { Grande } \\
\text { multipara }\end{array}$ & 11 & 3.0 \\
\hline Total & 367 & 100.0 \\
\hline
\end{tabular}

Table 2 shows that most pregnant women's parity is Nullipara as many as 140 people (38.1\%).

Table3. Frequency distribution of hypertension in pregnancy

\begin{tabular}{|c|c|c|}
\hline Hypertension & Frequency (n) & Percentage (\%) \\
\hline Yes & 32 & 8.7 \\
\hline No & 335 & 91.3 \\
\hline Total & 367 & 100 \\
\hline
\end{tabular}

Table 3 shows that pregnant women with hypertension were 32 (8.7\%). 
Table4. The relationship between maternal age and hypertension during pregnancy

\begin{tabular}{|c|c|c|c|c|c|}
\hline \multirow[t]{2}{*}{ Ages } & \multicolumn{2}{|c|}{ Hypertension } & \multirow[t]{2}{*}{ Total } & \multirow{2}{*}{$\begin{array}{c}\text { r- } \\
\text { value }\end{array}$} & \multirow{2}{*}{$\begin{array}{c}\text { p- } \\
\text { value }\end{array}$} \\
\hline & Yes & No & & & \\
\hline$<20$ years & 0 & 11 & 11 & \multirow{3}{*}{$\begin{array}{c}- \\
0.114\end{array}$} & \multirow[t]{3}{*}{0.029} \\
\hline 20-35 years & 19 & 243 & 262 & & \\
\hline$>35$ years & 13 & 81 & 94 & & \\
\hline Total & 32 & 335 & 367 & & \\
\hline
\end{tabular}

Table 4 shows that out of 367 pregnant women, the age group of 20-35 years old had hypertension of 19 people (7.81\%), while in the age group > 35 years with hypertension of 13 people $(16.04 \%)$. In the other hand, in the age group <20 years, no one had hypertension. Spearman Rank statistical test results obtained the $p$-value of 0.029 and $r$ values of -0.114 which is smaller than 0.05 indicating there is a relationship between age with the incidence of hypertension in pregnancy.

Table5. The relationship between parity and hypertension during pregnancy

\begin{tabular}{|c|c|c|c|c|c|}
\hline \multirow[t]{2}{*}{ Parity } & \multicolumn{2}{|c|}{ Hypertension } & \multirow[t]{2}{*}{ Total } & \multirow{2}{*}{$\begin{array}{c}\mathrm{r}- \\
\text { value }\end{array}$} & \multirow{2}{*}{$\begin{array}{c}\mathrm{p}- \\
\text { value }\end{array}$} \\
\hline & Yes & No & & & \\
\hline Nullipara & 5 & 135 & 140 & \multirow{4}{*}{$\begin{array}{c}- \\
0.143\end{array}$} & \multirow[t]{4}{*}{0.006} \\
\hline Primipara & 12 & 98 & 110 & & \\
\hline Multipara & 13 & 93 & 106 & & \\
\hline $\begin{array}{l}\text { Grande } \\
\text { multipara }\end{array}$ & 2 & 9 & 11 & & \\
\hline Total & 32 & 335 & 367 & & \\
\hline
\end{tabular}

Table 5 shows that of 367 pregnant women, in the Nullipara group of 5 people $(6.65 \%)$, in primipara group of $12(12.24 \%)$, in the multipara group with hypertension of 13 $(13.97 \%)$, while in the grande-multipara group a total of 2 people $(22.22 \%)$. Spearman Rank statistical test results obtained the p-value of 0.006 and $\mathrm{r}$ values of -0.143 smaller than 0.05 indicating there is a relationship between parity with the incidence of hypertension in pregnancy.

\section{Discussion}

Based on research that has been done, out of 367 pregnant women who do the outpatient examination in clinical birth, $71.4 \%$ are expectant mothers with age between 20-35 years, $25.6 \%$ are expectant mothers with age> 35 years, while $3 \%$ is $<20$ years old.

According to Fraser (2009), women whose age is less than 20 years have reproductive organs which are not functioning correctly, and the strength of abdominal muscles has not worked optimally. This condition will make the pregnancy and birth will be easy to experience complications. Furthermore, at the age above 35 years, the women have risk three times higher difficulty compared with average age group reproduction.

The research also revealed that from 367 pregnant women who do the outpatient examination in clinical birth, the most parity is Nullipara that is $38,1 \%$, primipara $30,0 \%$, multipara $28,9 \%$ and grande multipara $3.0 \%$.

According to Radjamuda \& Montolalu (2014), the safe parity without complications is under the number of birth 1-3 times. This condition means that Nullipara parity is at risk for complications of pregnancy that may cause pregnant women too often experience complaints, so they are more likely to have their pregnancies checked.

Based on the research, 367 pregnant women who had outpatient in clinical birth, 32 people (8.7\%) had hypertension, and 335 (91.3\%) had no hypertension.

According to Kamaliah (2010), pregnancy is a process of reproduction that needs attention to run well. Pregnancy is the life of the mother and fetus, the risk of pregnancy is dynamic because pregnant women who initially healthy suddenly can be at risk for complications. According to Llewellyn \& Jones (2002), complications of hypertension in pregnancy occur about 5-8 percent.

Spearman Rank statistical test results obtained the $p$-value of 0.029 and $r$ value of -0.114 with a significance level of 5\%. So it can be concluded that the value of $\mathrm{p} 0.029<0.05$ which means Ho is rejected and $\mathrm{Ha}$ accepted, or there is a relationship between age with the incidence of hypertension in pregnancy. $\mathrm{R}$ value of -0.114 shows the level of shallow relationship and the presence of a negative correlation, or the lower the age, the higher the risk of hypertension in pregnancy.

This study is inconsistent with the theories written by Djannah (2010) which says that hypertension in pregnancy is more common in early and late reproductive years of adolescence or over 35 years. The age of pregnant women $<20$ years is easy to increase blood pressure and faster cause seizures, while the age of pregnant women> 35 years is also a predisposing factor for the occurrence of hypertension in pregnancy. Also, age is also the more susceptible incidence of increased incidence of chronic hypertension and face a greater risk of suffering from hypertension in pregnancy. 
In the correlation test results, this study is by the results of Jamli (2007), which states that there is a relationship between the age of pregnant women with hypertension. According to Suprihatiningsih (2009), this is because age between 20-35 years may be more prone to pregnancy complications 2-5 times more than those aged between 20-29 years.

Based on the results of the study showed there is a shallow relationship between parity with the incidence of hypertension in pregnancy at the General Hospital Kraton Pekalongan. The value of $\mathrm{r}-0.143$ and $\mathrm{p}$-value of 0.006 with a significance level of $5 \%$. Besides, the $\mathrm{r}$ value in this study also showed a negative relationship or the lower the parity, the greater the risk of experiencing hypertension in pregnancy. So the results of this study following the results of research Harefa (2010), which states that there is a relationship between parity with hypertension in pregnancy.

\section{CONClusion}

- Most of the pregnant women at General Hospital of Kraton Pekalongan is the age group between 20-35 years as many as 262 people $(714 \%)$.

- Most of the pregnant women in General Hospital of Kraton Pekalongan is nullipara group as many as 140 people (38.1\%).

- The incidence of hypertension in pregnancy at the General Hospital of Kraton Pekalongan is as many as 32 people (8.7\%).

- There is a relationship between age with the incidence of hypertension during pregnancy at the General Hospital of Kraton Pekalongan with $p$-value 0.029 and value of $r$ 0.114 .

- There is an association between parity with the impact of hypertension during pregnancy at the General Hospital of Kraton Pekalon- gan with p-value 0.006 and value of $\mathrm{r}-0.143$.
The premises of health services need to increase the extension activities on every examination of pregnant women in clinical birth that can be done by health workers. The service is especially about hypertension in pregnancy so that the incidence of complications of hypertension in pregnancy and maternal mortality can decrease.

\section{REFERENCES}

[1] Djannah SN, Arianti IS. Gambaran Epidemiologi Kejadian Preeklampsi/ Eklampsi di RSU PKU Muhammadiyah Yogyakarta Tahun 2007-2009. Tesis 2010.

[2] Fraser, Cooper. Myles Buku Ajar Bidan Edisi 14. Jakarta: EGC; 2009.

[3] Harefa SY. Hubungan Karakteristik Ibu Hamil dengan Kejadian Preeklampsi/Eklampsi di Rumah Sakit Santa Elisabeth Medan, Tesis 2010.

[4] Jamli. Hubungan Beberapa Karakteristik Ibu Hamil dengan Kejadian Preeklampsi (Studi Kasus di Rumah Sakit Bersalin Sayang Ibu Kecamatan Balikpapan Barat Kota Balikpapan Tahun 2006. Tesis 2007.

[5] Kamaliah. Beberapa Faktor yang Berhubungan dengan Terjadinya Komplikasi Kehamilan dan Persalinan di Rumah Sakit Haji Medan Tahun 2002-2003. Tesis, 2009.

[6] Llewellyn \& Jones.D, Dasar-dasar Obstetri \& Ginekologi. Jakarta: Hipokrates; 2002.

[7] Prawirohardjo S. Buku Acuan Nasional Pelayanan Kesehatan Maternal dan Neonatal. Jakarta: Yayasan Bina Pustaka; 2009.

[8] Prawirohardjo S. Ilmu Kebidanan. Jakarta: Yayasan Bina Pustaka Sarwono Prawirohardjo; 2008.

[9] Radjamuda, N., \& Montolalu, A. (2014). FaktorFaktor Risiko Yang Berhubungan Dengan Kejadian Hipertensi Pada Ibu Hamil Di Poli Klinik Obs-Gin Rumah Sakit Jiwa Prof. Dr. VL Ratumbuysang Kota Manado. JIDAN-Jurnal Ilmiah Bidan, 2(1).

[10] Suprihatiningsih. Faktor-Faktor Yang Berhubungan Dengan Kematian Neonatus Di Kota Metro Tahun 2009. Jurnal Kesehatan "Metro Sai Wawai" Vol. II No. 2 Edisi Desember 2009

Citation: Suryo Pratikwo, Ida Baroroh \& Agustiana Resghyanti. The Effect of Age and Parity on Hypertension during Pregnancy. ARC Journal of Nursing and Healthcare. 2017; 3(2):1-7. doi: dx.doi.org/ 10.20431/2455-4324.0302001

Copyright: (1) 2017 Authors. This is an open-access article distributed under the terms of the Creative Commons Attribution License, which permits unrestricted use, distribution, and reproduction in any medium, provided the original author and source are credited. 